\title{
MAPPING SURFACE AND SUBSURFACE KARST GEOHAZARDS FOR HIGHWAY PROJECTS: SR 71 SOUTH KNOXVILLE BOULEVARD EXTENSION, KNOX COUNTY, TENNESSEE
}

\author{
Harry L. Moore \\ Golder Associates/Tennessee Dept. of Transportation -Retired, 3730 Chamblee Tucker Rd., Atlanta, Georgia 3034, \\ 865-603-7652,HLMoore@golder.com
}

\begin{abstract}
The proposed extension of SR 71 (South Knoxville Boulevard) located in Knoxville, Tennessee necessitated a preliminary geologic evaluation of the corridor which was under consideration by the Tennessee Department of Transportation. A geohazards review disclosed the presence of extensive karst terrain located within the corridor being considered. A number of caves were also found during the investigation. The proposed routes within the study corridor were found to cross a series of very large multiple hectare (acre) sinkholes. In addition, a biological investigation of the route revealed the presence of a rare and endangered species of cave salamander called the Berry Cave Salamander.
\end{abstract}

The geologic and geotechnical investigation resulted in the development of a surface karst map of the study corridor. Sinkholes and cave entrances were located and a generalized karst boundary was established. In addition, a survey map of the Meades Quarry Cave was made which provided supporting quantitative data in connecting surface sinkholes and the cave containing the endangered Berry Cave Salamander. A recommendation of the study was a dye tracing of the suspect sinkholes. If this highway project is constructed, then measures will be required to mitigate the effects of the highway run off in the karst terrain affecting the Berry Cave Salamander.

\section{Introduction}

Large areas of East Tennessee are underlain by carbonate rocks such as limestone and dolostone with some estimates of as much as $50 \%$ to $60 \%$ of all underlying rock types being carbonates. As a result, these areas are subject to solution type chemical weathering and the resulting karst landform development, such as sinkholes and cave systems.

The Tennessee Department of Transportation (TDOT) is planning a new roadway alignment (SR 71) that crosses portions of South Knox County in East Tennessee. The proposed corridor is located in a section of the Valley and Ridge Province of East Tennessee where several ridges and valleys will be crossed, as well as creeks, roads, subdivisions and rural lands (Figure 1). The proposed corridor connects the current terminus of SR 71 at Moody Ave. in South Knoxville to John Sevier Highway (SR 168).

In an attempt to properly evaluate the potential for geologic hazards along the project, an effort was made to locate all sinkholes and caves within the project area, karst being the primary geologic hazard identified. To this effort, a karst map and a map of one cave was completed.

\section{General Geology of Proposed Corridor}

The proposed corridor is situated in the rolling to hilly topography of the Valley and Ridge Province of East Tennessee and includes a portion of South Knox County (Figure 2). Geologically, the corridor is situated in terrain underlain by folded and faulted sedimentary strata composed of several major rock types including limestone, shale, sandstone, and siltstone.

The geologic formations that underlie the study area are part of the middle-Ordovician Chickamauga Group and include the Lenoir Formation-Ol (argillaceous limestone), Holston Formation-Oh (marble, crystalline limestone), Chapman Ridge Formation-Ocr (sandstone), and the Ottosee Formation-Oo (shale, siltstone, and limestone). These formations have geologically normal conformable stratigraphic contacts and comprise the major portions of a large flexure anticlinal fold (Figure 3) (W. D. Hardeman, 1966).

In general terms, the bedrock has a northeast to southwest trending strike with bedding that dips to the southeast. In addition, there is a southwest plunging anticline, known as the Rocky Valley anticline, located within the center 


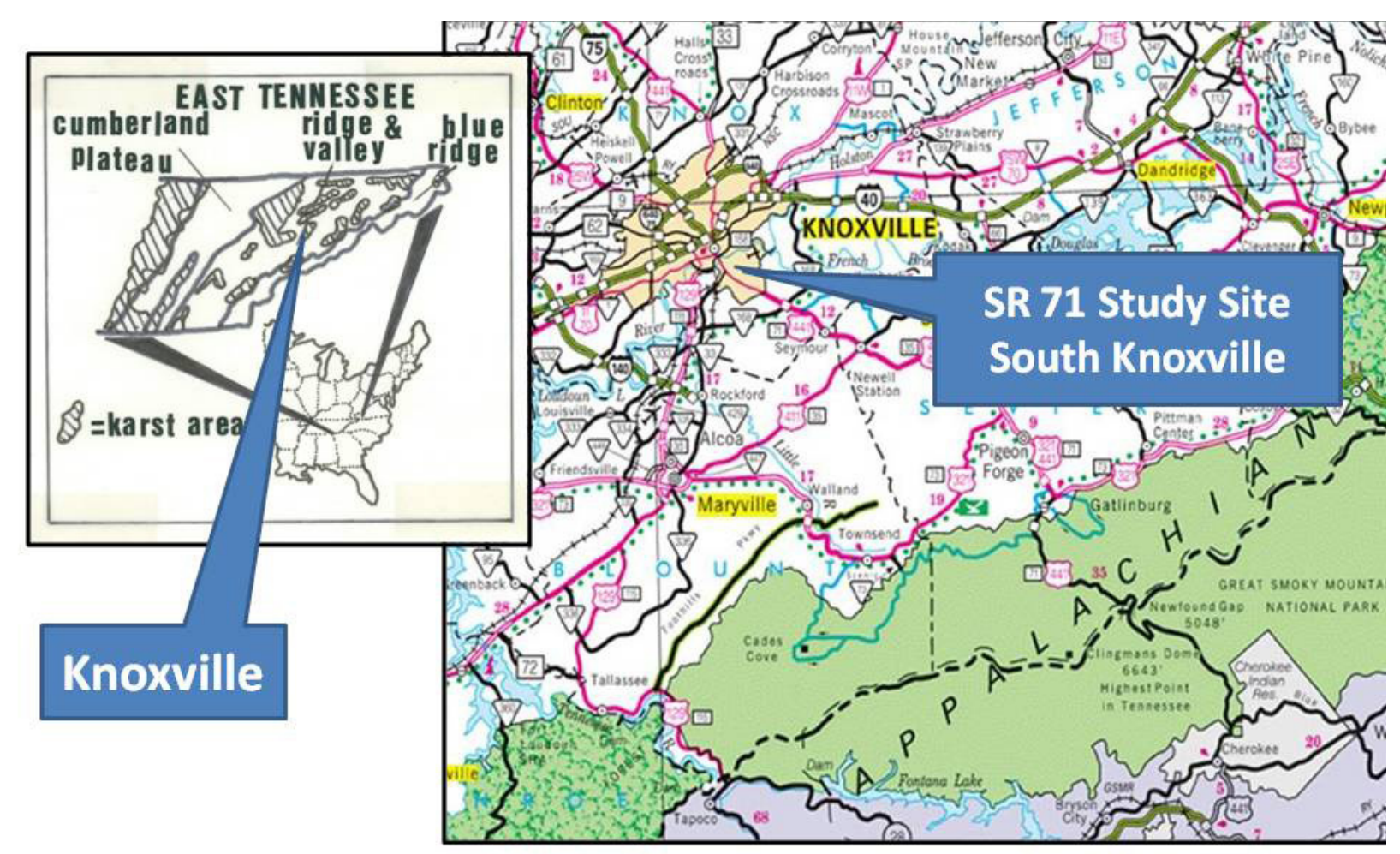

Figure 1. General location map of the SR 71 study area in Knoxville, Tenn.

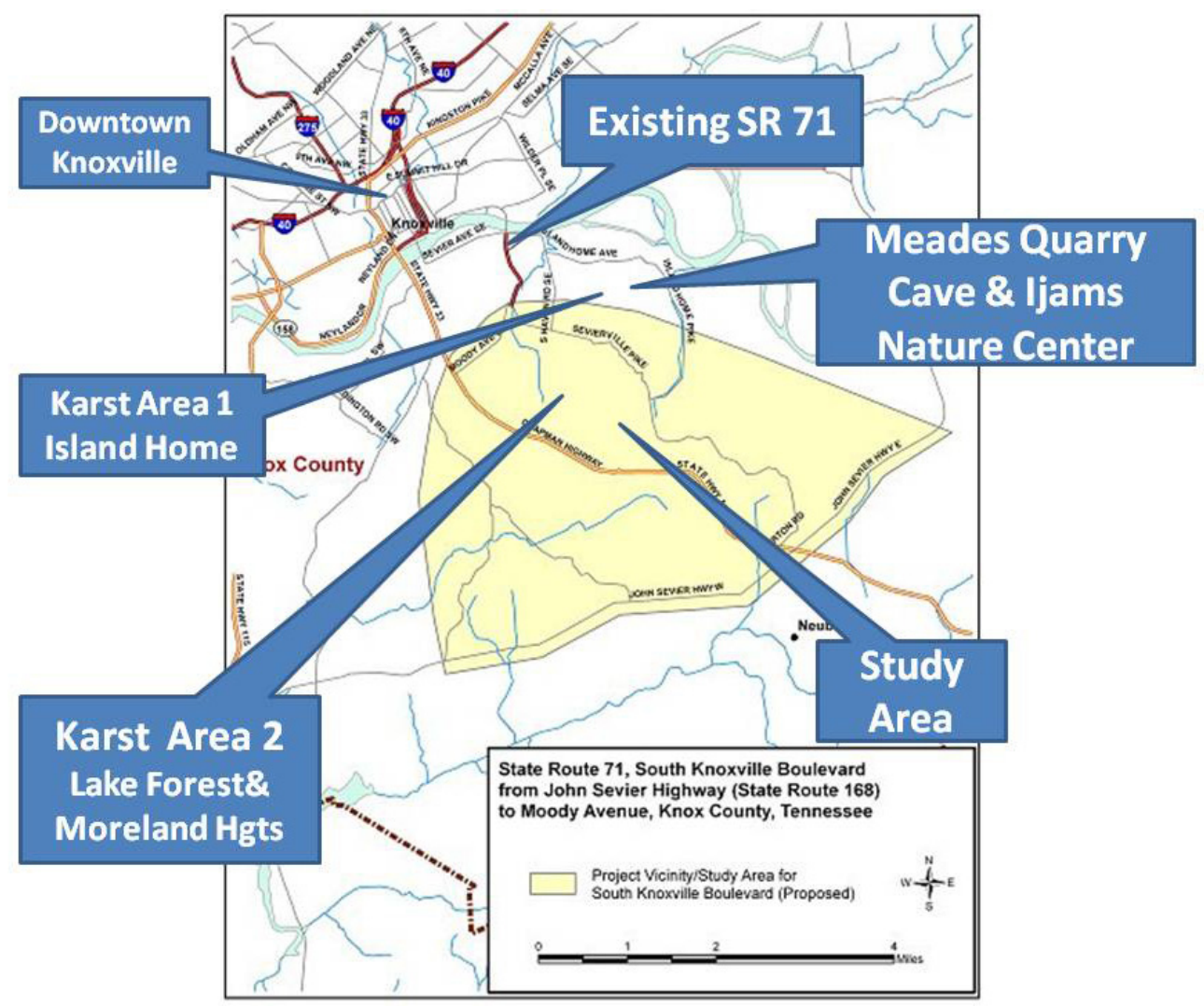

Figure 2. Location of SR 71 study area in South Knoxville; Noted are Karst Area 1 and 2 and Meades Quarry Cave locations. 


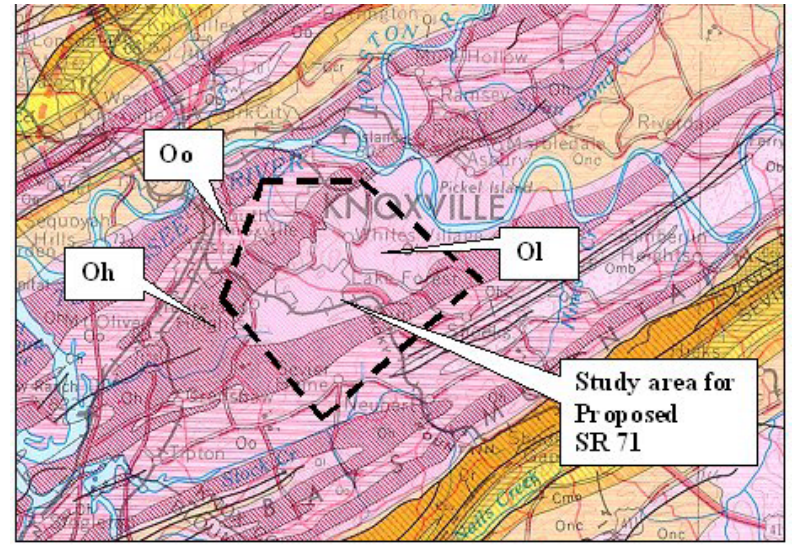

Figure 3. Geologic Map of the study area; OlLenoir Fm.; Oh-Holston Fm.; Oo-Ottosee Fm.

of the study area and extends from near the French Broad River/Holston River confluence(the beginning of the Tennessee River) to the southwest part of Knox County. Due to the anticline structure, some strata located on the northwest limb of the structure dip to the northwest and form a limb of a small syncline, the Island Home Syncline.

The rock units are structurally oriented in a northeast to southwest position with the rock layers (bedding) dipping generally to the southeast at varying angles. Numerous fractures and other discontinuities are found throughout the strata along the study corridor and are the result of the intense folding and faulting history of the region.

Weathering has also produced knobby terrain and classic karst topography characterized by sinkholes, disappearing streams, and caves. Notable caves found in the study area include Cruze Cave and Meades Quarry Cave.

\section{Geohazards Evaluation}

Geologic hazards include such things as existing landslides or areas prone to landslides, the presence of acid producing rock, soft or weak soil, old abandoned mine sites, contaminated ground, caves and sinkhole areas (referred to collectively as karst), and earthquake prone areas.

With the exception of karst, abandoned quarry pits, and steep terrain, geologic hazards do not pose an immediate threat to the environment and public along the study corridor. The most significant hazard along the proposed corridor is karst, which is located in belts or zones that trend in a northeast-southwest direction.
The karst landscape of the study corridor as well as the rest of East Tennessee is characterized by features such as sinkholes, caves and cave entrances, sinking streams and outcroppings of weathered carbonate rock (limestone and dolostone). There have been incidences of sudden sinkhole collapse as well as flooding of sinkhole basins crossed by roads or buildings. The recognition of areas of active karst subsidence and collapse is of considerable importance to the design and construction of the proposed highway.

TDOT initiated a karst geohazards inventory and assessment to assist in evaluating and selecting a satisfactory alignment within the corridor study area. This study was designed to locate caves and sinkholes within and adjacent to the proposed corridor (Figure 4).

In addition, the caves were visited and preliminarily evaluated as to their geotechnical and environmental importance. The caves that were found to be of significance to the proposed stability of the roadway or have environmental and archeological significance were surveyed to determine their lateral and vertical extent. Mapping of the caves was performed by both TDOT Geotechnical Engineering staff and local speleologists.

Caves and sinkholes offer special challenges relative to both the physical and environmental issues of highway development. The karst geohazards inventory study disclosed the presence of both sinkholes and caves, some of which may have detrimental structural, geologic, and environmental issues for the roadway alignment and grade design considerations.

A total of eight caves as well as numerous sinkholes were located within the proposed roadway corridor. Two of the caves, Cruze Cave and the Meades Quarry Cave System, were determined by the TDOT Geotechnical Section (Knoxville office) to be significant enough to require more in-depth study and analysis.

For reasons of sensitivity concerning cave conservation and landowner privacy, the cave locations are not specifically detailed in this paper; however, their names and locations are maintained in the files of the TDOT Geotechnical Engineering Section (Knoxville office) for reference when needed. Of recent note, Meades Quarry Cave (all entrances) has been gated by the Ijams Nature Center Park to control access to the cave system. 


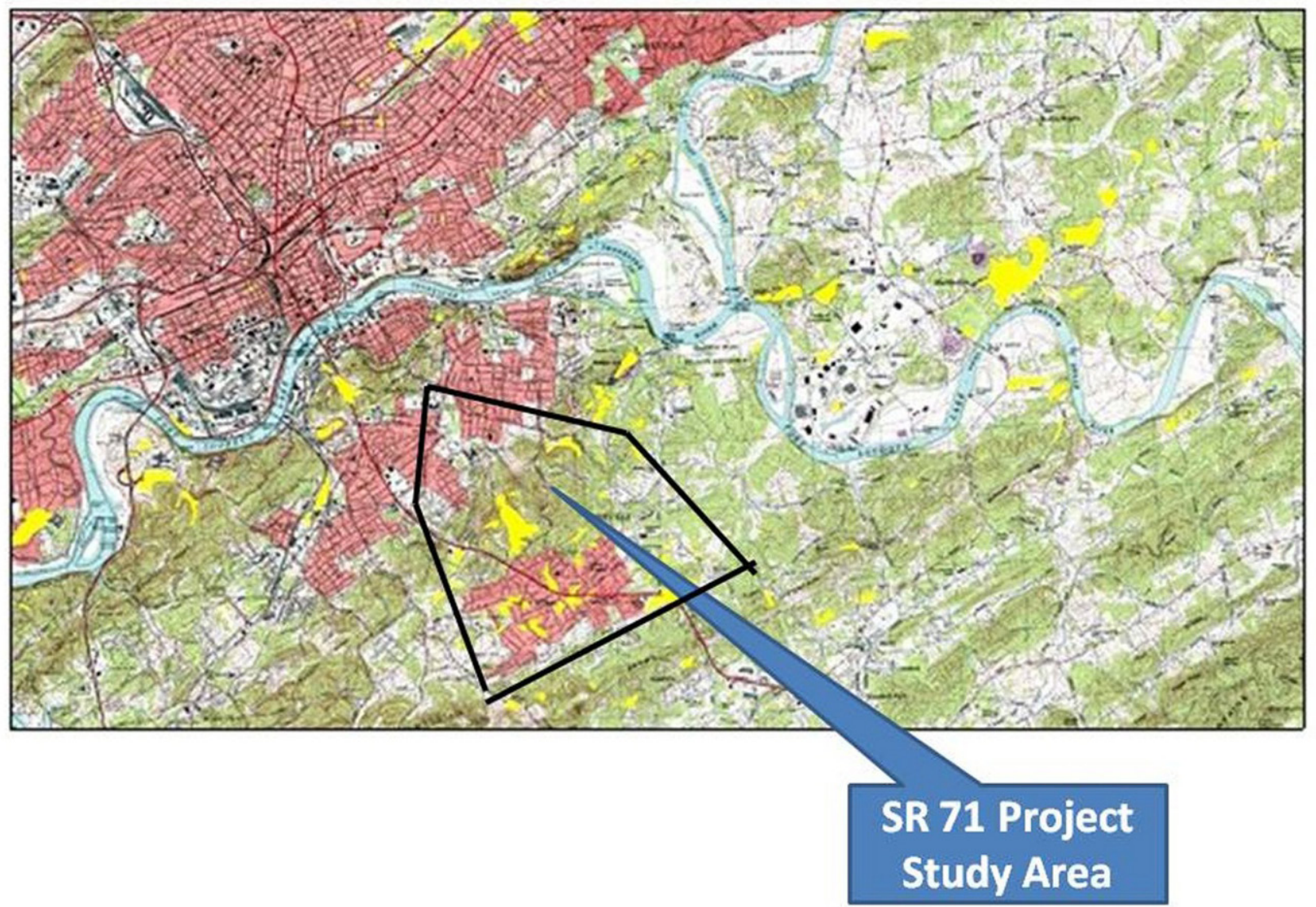

Figure 4. This sinkhole map was prepared for the geohazard study for the SR 71 project; yellow areas are sinkholes that were found based on a 20 -foot contour interval.

\section{Mapping Karst Areas within the Proposed Study Corridor}

Efforts to avoid karst areas with roads and other developments are difficult at best, especially since the "good" land is already mostly developed, leaving only the geologically undesirable land for current development. Geologically undesirable land found along the proposed highway corridor includes such areas as karst terrain and steep, very rocky terrain.

In planning new highway corridors certain constraints must be known and when identified are usually displayed by mapping. The first step in a karst geohazard study is to map the surface karst features. The TDOT Geotechnical Engineering Section mapped the karst features in an effort to identify geohazard areas.

In general, 7.5 minute topographic maps (that use a 6 meter (20 foot) contour interval) were used to locate karst features such as sinkholes (closed depressions on the contour map), caves, springs, and sinking streams. Once these karst features were identified and located on the topographic maps (Figure 4), then a field reconnaissance was performed to field check the features to make sure that they were there.

Afterwards, the sinkholes and other karst features were enhanced on the topographic maps and subjective boundaries were drawn to encircle these areas. Typically, these encircled areas are identified as "areas of high concentrations of sinkholes" and/or "areas of numerous cave openings". Actual cave entrances were not plotted on the final geohazard map due to access issues and private owner protection.

The geohazard areas were then expressed as outlined patterns on topographic maps to better illustrate the geohazard relative to the surrounding landscape. In addition, the proposed corridor route was overlain on the geohazard map. This map is then used by the roadway planners to better locate the final roadway centerline.

In some cases, maps with contour intervals as small as 0.3 to 1 meter (one to three feet) are available which 
greatly enhances the sinkhole identification (Moore and McDowell, 2008). David A. Hubbard (2003) researched this issue in the karst regions of the Valley and Ridge of Virginia where he consistently identified more sinkholes on the ground than were depicted on selected 7.5 minute quadrangle maps. In one instance Hubbard described a 7.5 minute quadrangle with a 6 meter (20 foot) contour interval that revealed 55 sinkhole features, while ground field mapping identified 533 sinkhole features.

In addition to the surface mapping of sinkholes, it is becoming increasingly important to locate (step two in the geohazard study) and map the caves(step three in the study of karst geohazards) in close proximity to the proposed roadway. By knowing spatial locations of the cave passages, a more accurate design of proposed roadway cut slopes can be made. This prevents the unnecessary opening of a cave system to the surface, thus protecting the cave biota, such as bat colonies and salamanders.

The use of experienced cavers in combination with engineering survey crews provided the best results for locating the cave passages spatially with respect to the proposed roadway. It is anticipated that mapping of cave passages will become increasingly mandatory as society continues encroaching onto and into the karst environment.

After a review of available geologic data and field investigations, the SR 71 Extension corridor was found to be located within several strike belts of karst.

Numerous sinkholes and caves were found to be located in these karst areas. The most intensive sinkhole areas were mapped in order to better assess the corridor terrain (Figure 5). A field reconnaissance of the study area was made in order to locate as many sinkholes as possible. Many were overgrown and difficult to locate. A few of the caves that were identified were found to be located outside of the sinkhole zones (outlined on the attached karst-sinkhole map), but within typical karst terrain.

The possible impacts from the proposed road alignment (or any other structure, building, subdivision, etc.) on the karst environment include sinkhole collapse, sinkhole flooding, groundwater contamination and negative effects on the cave and subsurface dwelling wildlife.

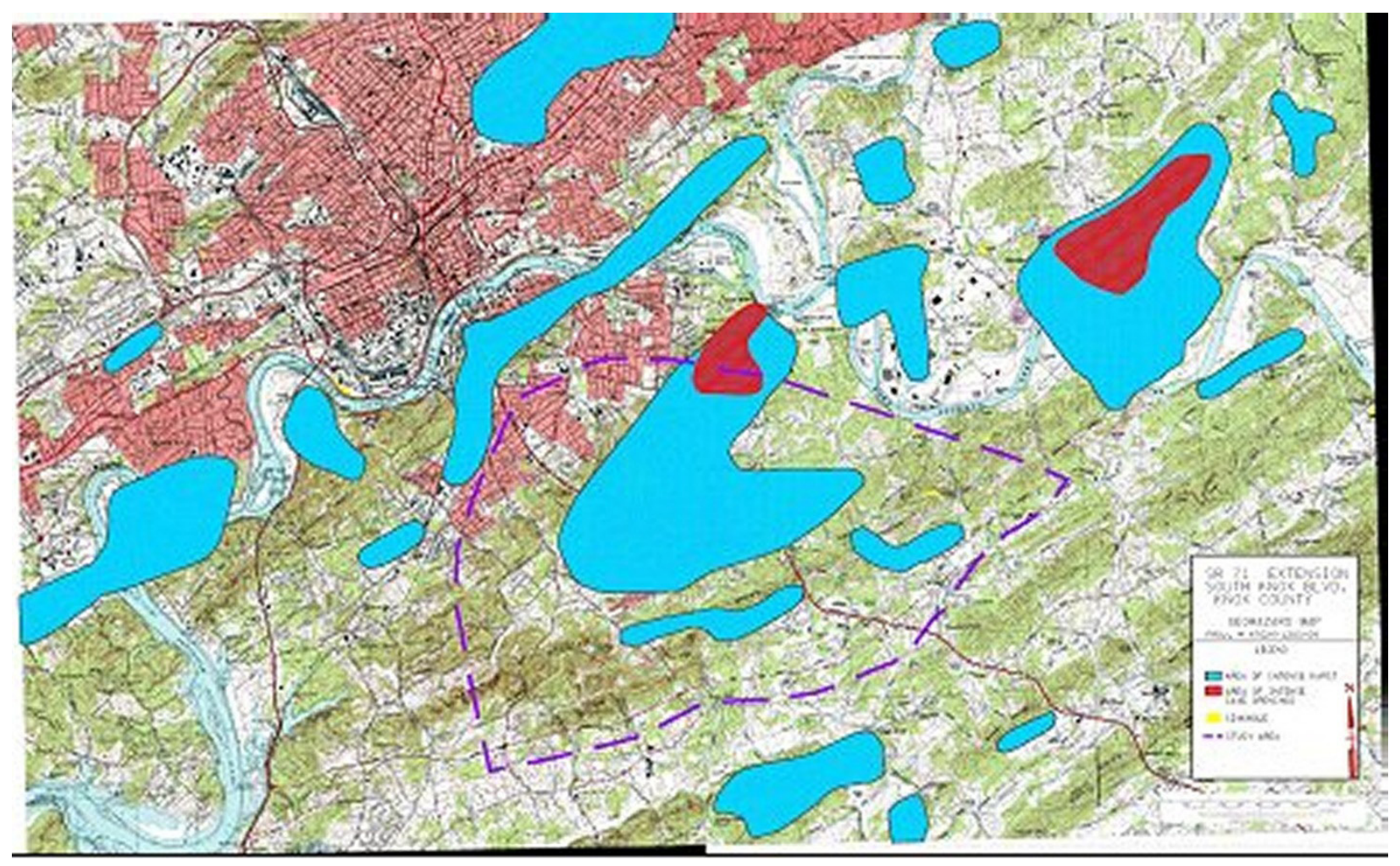

Figure 5. Karst Map of study area (dashed line); blue is active/intensive sinkhole area, red is area of caves, downtown Knoxville is pink area in upper part of map. 
Two major sinkhole areas were found within the proposed study corridor. These include the area just southeast of Island Home (including old abandoned marble quarries) and the Lake Forest/Moreland Heights communities. The following is a brief discussion of these two karst areas.

\section{Karst Area 1}

Karst area 1 is located in the northern part of the study area ( see Figure 2) and is developed along the bedrock strike of the Holston Formation, and to a lesser extent, the Lenoir Formation. Numerous unique formations and biota, including several species of bats and salamanders, are found in many of the caves in this area.

The Holston Formation strata have been quarried as "Tennessee Marble" in the historic past, as evidenced by several old abandoned quarry pits in the Meades Quarry section off of Island Home Avenue. The quarrying operations have exposed a cave system and underground stream in several areas of the abandoned quarry pits. Five openings into the cave system were found in the old pit areas. The cave is known as Meades Quarry Cave.

Another cave in this karst area is known as "Un-named Cave", and is located next to Island Home Avenue, approximately one-half mile south of the Meades Quarry area. Entrance into the cave is very limited due to a spring that issues out of the submerged entrance. Several other large sinkholes are also found in this area, mostly to the west of Island Home Avenue.

A third cave, Cave Spring Caves, is found along the Tennessee River bluffs in what is known as Ijams Nature Park. These short double caves, approximately 24 meters (80 feet) in length), are developed in sandstone strata of the Chapman Ridge Formation. Meades Quarry Cave is also found in the Ijams Nature Park in an area to the southwest of the Tennessee River.

The karst in this area is characterized as being well developed with numerous sinkholes, open solution channels, and solution cavities located well above the zone of saturation ( vadose zone). Naturally developed cave entrances tend to be in the floors of sinkholes which drain surface run-off into the vadose zone. In some instances deep soil-cover mantles the underlying bedrock which is characteristically carbonates, shale, and sandstone, are also tilted and pinnacled.

\section{Karst Area 2 in the Lake Forest/ Moreland Heights Communities}

Karst Area 2 is located near the center of the study area and encompasses the heavily populated communities of Lake Forest and Moreland Heights (see Figure 2). Numerous sinkholes are found in this area, some of which are water-filled. Three caves are located in this area and are locally known as Brown Cave, Backyard Cave, and Cruze Cave.

Two geologic formations found in this section (Holston Formation and Lenoir Formation) have karst features that are prevalent across much of the area. The area that is underlain by the Lenoir Formation tends to have relatively moderate to low relief with thin soil cover and broad sinkholes. The Holston Formation tends to underlie high ridges and hilly terrain, and produces a rich, maroon-red clay residual soil mantle. This Holston derived soil is variable in thickness, but can attain thicknesses up to 15 to 18 meters (50 to 60 feet).

Cruze Cave was visited by the author. The cave is apparently developed both in the Holston and Lenoir formations and tends to follow the dip of the bedrock as it plunges downward with the structure of the geologic anticline. The roof of the cave along with some of the upper passages were found to be developed in the Holston Formation, while the current active stream drainage conduit is developed in the Lenoir Formation.

\section{Mapping Subsurface Karst: Meades Quarry Cave Mapping Initiative}

Due to the existence of Meades Quarry Cave within the proposed study area, it was decided to map the western-most portion of the cave system. The purpose of mapping the cave was to determine if the general trend of the cave and cave stream is toward the sinkhole area around Old Sevierville Pike and Red Bud Drive, which is located within the study area of the proposed parkway extension.

The presence of the Berry Cave Salamander (Gyrinophilus gulolineatus, a subterranean amphibian listed as a potential threatened species - see Figure 6) in the Meades Quarry Cave stream has made the cave an important issue with respect to the proposed SR 71 extension. The Berry Cave Salamander derives its nutrition from debris and organics that are flushed into the sinkholes by rain events which in-turn recharge the 
cave stream in which the salamander lives. Sinkhole modifications would directly affect the salamanders.

In August 2008 the TDOT Geotechnical Engineering Section began mapping the western-most portion of the Meades Quarry Cave system. This section has its entrance in the floor of an old quarry pit where it was exposed during quarrying operations in the 1930's and 1940's (Figure 7). Initial mapping was by the tape and compass method, but difficulties due to the thick extensive mud deposits in the cave forced us to switch to using a hypsometer.

Two mapping trips were required to gain sufficient survey data for our objective of establishing a trend for the cave passages. The mapping was performed on August 5 and August 13 of 2008.

Briefly, the cave passage consisted of a main canyontype gallery that held a flowing stream in the floor of the passage. The cave is developed in the vadose zone and is floored at the vadose/phreatic contact. Some portions of the cave contained numerous dripstone formations (speleothems), some of which were a pure white color (Figure 8). Past wastes from a lime kiln operation at the quarry may have contributed to this white character. Thick mud deposits up to 0.3 to 0.5 meters (12 to 18 inches) thick were found on the stream bed and most exposed rock surfaces.

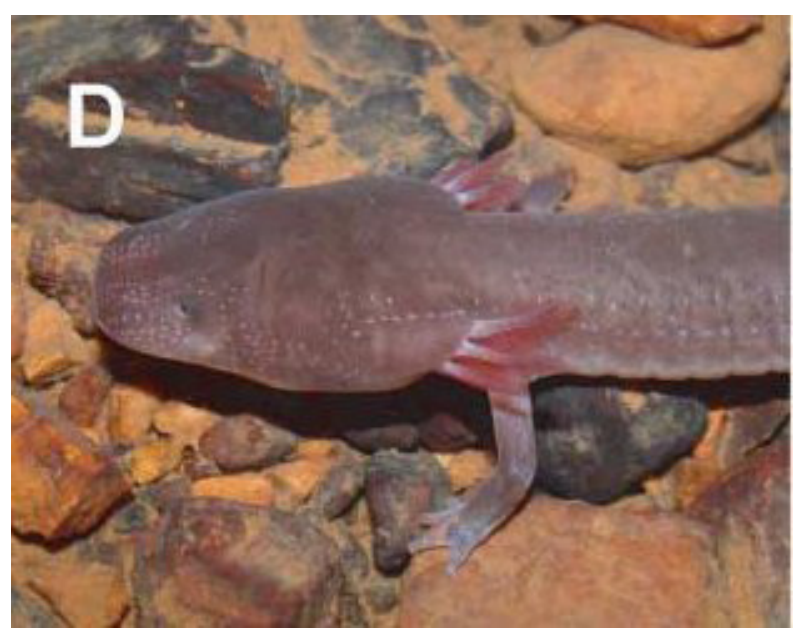

Figure 6. This photo shows the Berry Cave Salamander (Gyrinophilus gulolineatus) as found in Meades Quarry Cave by University of Tennessee researcher Matt Niemiller (photo by Niemiller from: http://www.herpetology.us/niemiller/).
From our mapping effort it was determined that the cave trends in an azimuthal direction of 248 degrees (or $\mathrm{S} 58 \mathrm{~W}$ from the cave entrance), which is toward the numerous sinkholes found along Old Sevierville Pike. A total of 399.4 meters (1,318 feet) of cave passage was surveyed (Figure 9 and Figure 10).

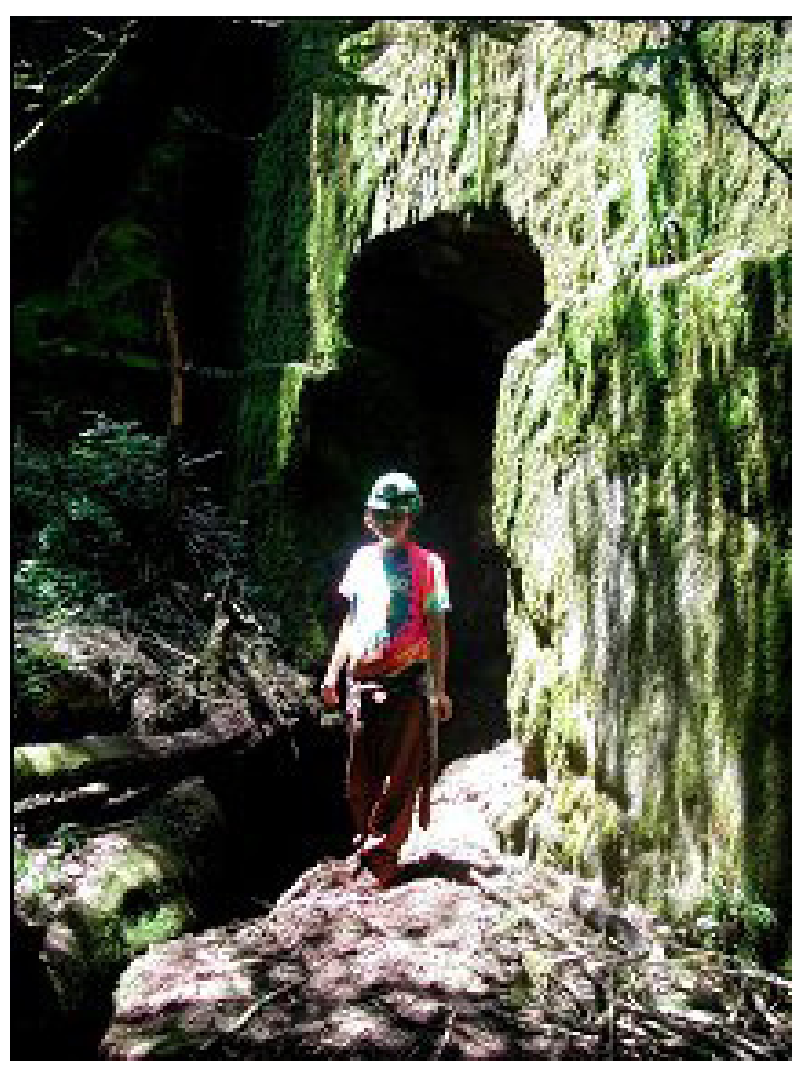

Figure 7. Man-made entrance to Meades Quarry Cave.

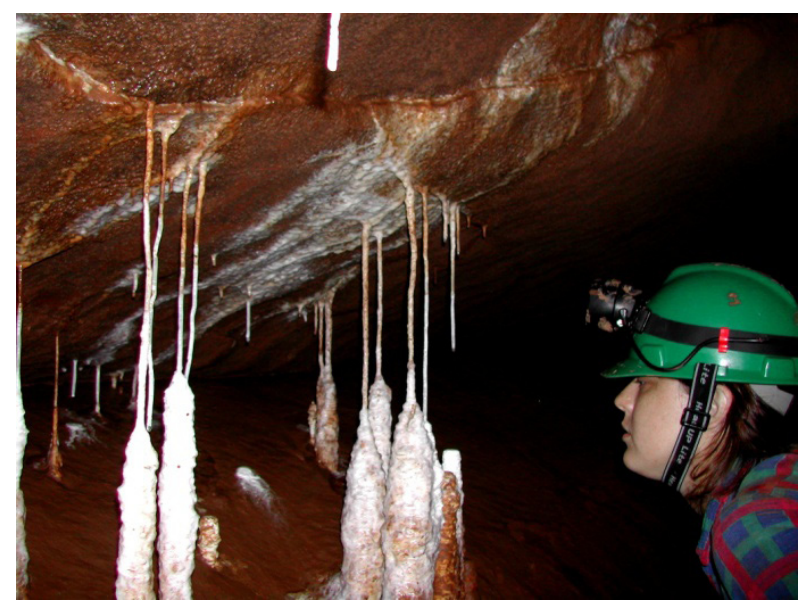

Figure 8. Unusual white soda straw formations in Meades Quarry Cave. 
Fracture type joints in the bedrock tended to form side passages through which groundwater may flow to the main stream gallery. These fracture joints were found to have two general orientations: N40 W and N35 E. The strike orientation of the bedrock (the Holston Formation) was found to be approximately North 55 degrees East.

Meades Quarry Cave is developed in a linear fashion which is sub-parallel to the strike of the bedrock and may tend to "bend" somewhat to the southwest near the upstream portions of the cave. The cave is developed in a limestone formation (Holston Formation) that forms the northwest limb of a southwest plunging anticline meaning that the bedrock is dipping to the northwest. It is interpreted that the joints which were located during the mapping program tend to dip toward the northwest as a result of being on the northwest limb of the anticline and reflects that structure orientation.

As a result of the geohazard investigation and mapping initiative, it was interpreted that the stream passage of Meades Quarry Cave does indeed lay within the study area of the proposed SR 71 extension.

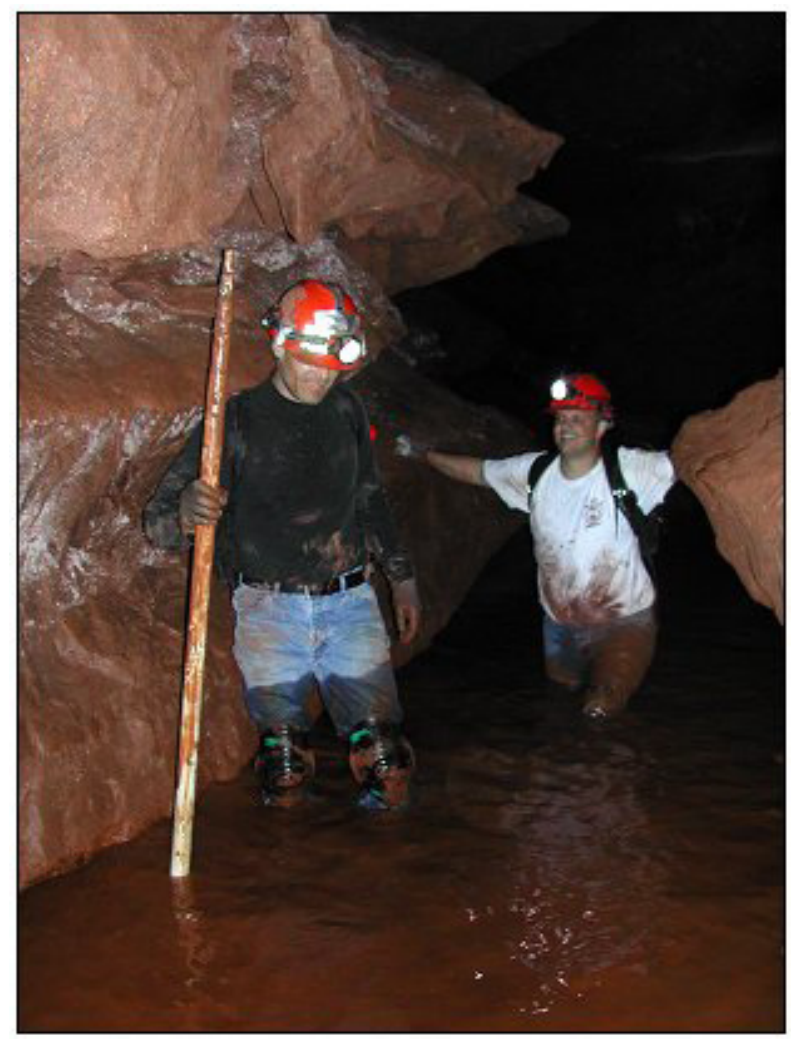

Figure 9. Mapping stream cave passage in Meades Quarry Cave.

\section{Conclusions}

The result of this paper is to show how mapping karst geohazards can be effective in geotechnical studies of proposed roadways. Three main steps are involved in the karst geohazard study: (1) - map all surface karst features; (2)- locate all cave entrances; and (3)- map cave passages suspected to be impacted by the proposed roadway.

The major geohazard issue found along the proposed South Knoxville Boulevard Extension (SR 71) corridor is karst. Karst is found in numerous areas of East Tennessee, predominantly in the Valley and Ridge Province. Long linear "belts" of sinkholes, caves, sinking streams, underground stream drainage, and "dry valleys" all characterize the karst in East Tennessee. Most counties in the East Tennessee region contain some amount of karst topography.

The proposed South Knoxville Boulevard Extension (SR 71) corridor likewise, has numerous karst features that are found within the area topography. Mapping surface and subsurface karst features greatly aided the evaluation of proposed roadway corridors A result of this study was the development of a surface karst map which showed areas of numerous sinkholes, which is interpreted as areas of potential future sinkhole development.

Mapping the Meades Quarry Cave System, located adjacent to the study area of SR 71, was determined to be feasible and necessary in order to ascertain the location of the Meades Quarry Cave passages which contain the Berry Cave Salamander. As a result, a portion of Meades Quarry Cave was mapped using both conventional tape and compass survey methods and hypsometer and compass methods.

The construction of road projects, as well as industrial sites, shopping malls, and subdivisions will be problematic in karst areas and should be avoided when possible. However, if avoidance is not possible, then minimization of the impact of construction on the sinkhole and cave environments should be the objective. Such design measures as minimal cut and fill construction and minimal alterations in the surface drainage of an area (both surface and subsurface) are recommended.

Mitigation of the impacts on the karst areas needs to be included with the roadway design and construction 


\section{Meades Quarry Cave Ijams Nature Center Knoxville, Tenn.}

Total Distance Surveyed: 399.4 meters (1318 feet)

\section{Scale:}

$-=6.1$ meters (20 feet)

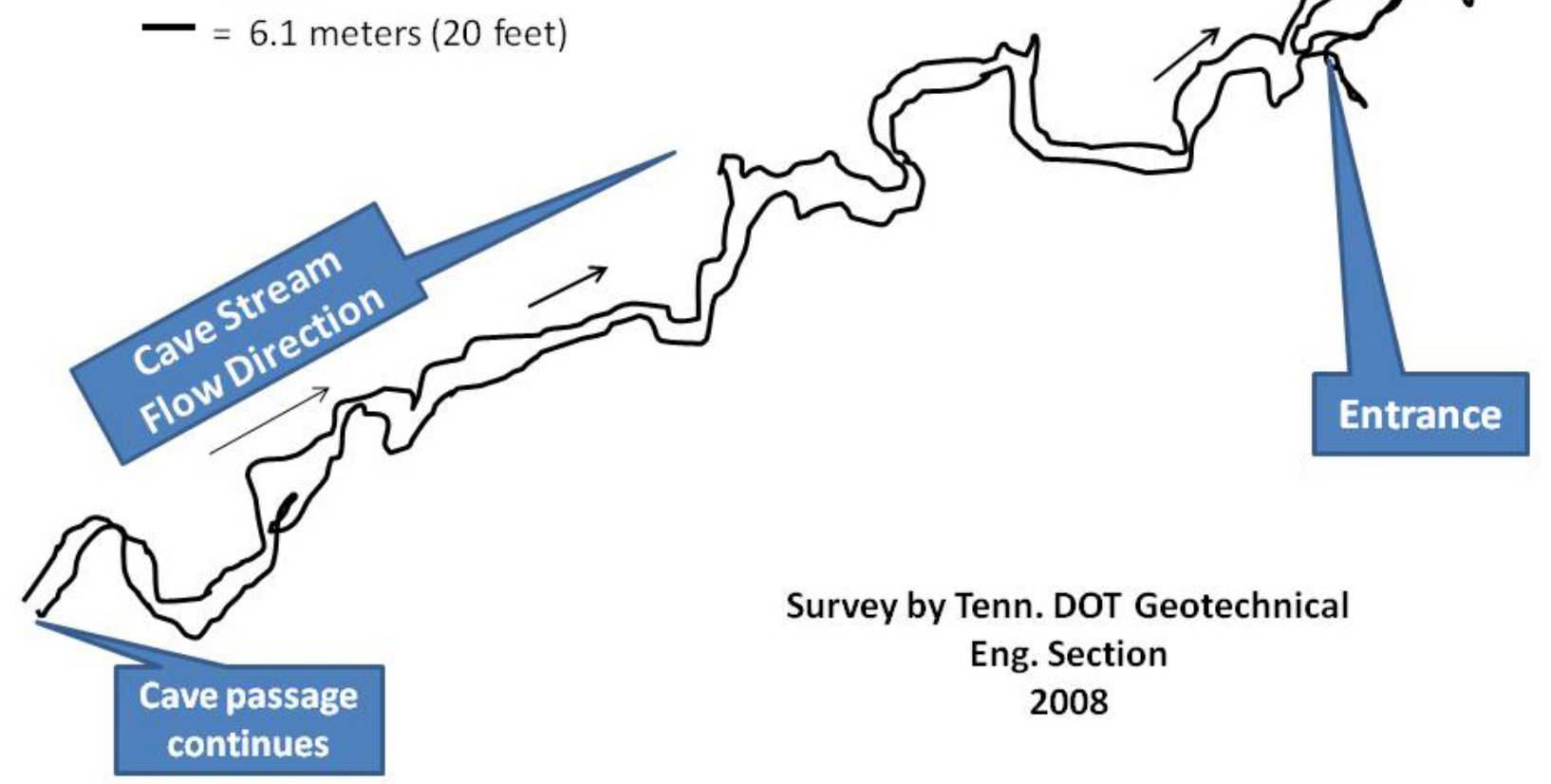

Figure 10. This map of Meades Quarry Cave, made by the TDOT Geotech section, shows the general stream flow direction, which is parallel to the bed rock strike direction.

plans. Proactive measures such as surface drainage filtration systems for sinkholes, impermeable lining for ditchlines (to prevent new sinkholes from forming), the use of graded rock embankments (for stability and groundwater impacts), and the use of structural bridges over sensitive sinkholes should be considered and/or employed during the roadway design phase.

Surface water run-off filtration systems have recently been constructed on a TDOT roadway project in Hamblen County, Tennessee where the run-off empties into a sinkhole. The filtration system design was based on results of a Federal Highway Administration (FHwA) Pooled Fund study that involved filtering highway run-off in karst areas. Tennessee DOT was a partner in the FHWA Pooled Fund study (Stephenson and Beck, 1995; Stephenson, et al., 1997).

The groundwater contamination issue is an important topic for this project due to the potential impact on the rare Berry Cave Salamander which lives in the Meades Quarry Cave System. Once a groundwater dye trace is completed, then a more appropriate evaluation of the karst groundwater drainage can be made.

It is important to understand that there will be an impact on the karst environment (sinkholes, caves, wildlife, and groundwater). In some places, this impact may be significant where caves and sinkholes are exhumed and/ or filled in with embankment material, and where surface drainage is directed into sinkholes that empty into the caves and groundwater systems. These impacts can be lessened by appropriate and judicious mitigation during the design and construction phase of the project.

The TDOT Geotechnical Engineering Section has already assisted the Planners and Designers in adjusting the alignment of several proposed routes and providing recommendations that minimized the impact 


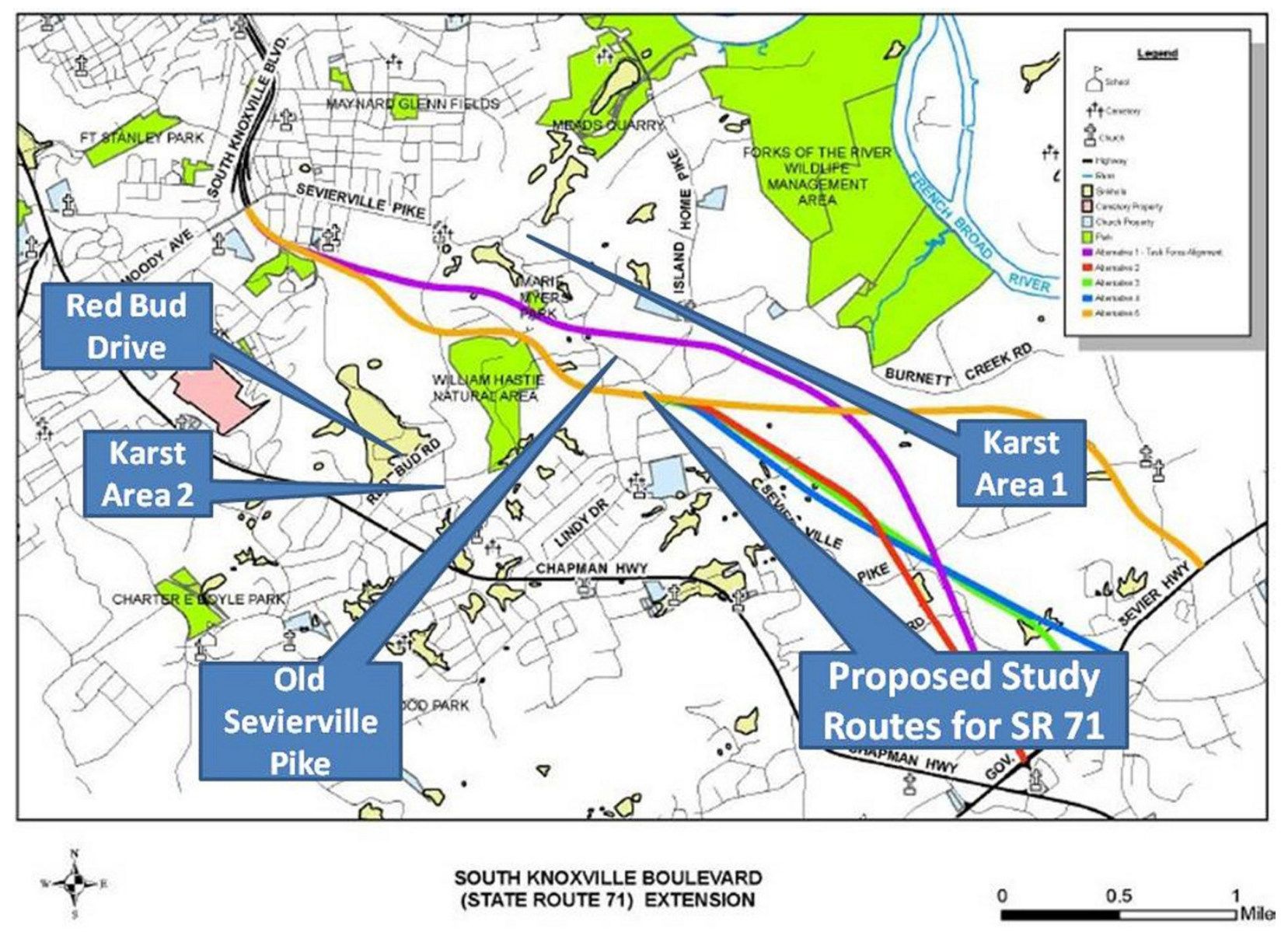

Figure 11. Map of SR 71 project area showing Karst Areas 1 and 2 and selected routes based on karst.

of the alignment on the known cave and karst systems (Figure 11). Projects involving karst are more costly on average than other projects, and cost overruns during construction should be anticipated due to the unknown and variable nature of karst features.

\section{Acknowledgements}

The Author wishes to acknowledge several people for their assistance in the development of this paper. Len Oliver, Manager, TDOT Geotechnical Engineering section, and David Barker, Manager of the Knoxville office of the TDOT Geotechnical Engineering section both offered their assistance and support for this study (before my retirement from TDOT). It was while I was with TDOT that I completed the field studies for the SR 71 project.

In addition, I wish to acknowledge Lori McDowell, TDOT Geotechnical Engineering Section -Knoxville Office for her support and assistance during the field investigation and cave mapping. Also, George Danker, Sam Williams, John Kizer, and Fred Barrell all from the TDOT Geotechnical Engineering Section are acknowledged for their help with the cave mapping effort.

\section{References}

Hardeman, W. H., 1966. Geologic Map of Tennessee.Tennessee Division of Geology, Department of Environment and Conservation, Nashville, Tenn.

Hubbard, David A., 2003. Use of regional sinkhole mapping for sinkhole susceptibility maps. ASCE Geotech. Special Publ. No. 122: Sinkholes and the Engineering and Environmental Impacts of Karst, proceedings of the 9th Multidisciplinary Conference on Sinkholes, ed. Barry Beck, Huntsville, Ala., Sept. 6-10,p. 61-71. 
Moore, Harry L., and Lori McDowell, 2008. The Development and Use of Karst Maps in the Location of Highways in East Tennessee. In Beck, B. F., ed., Sinkholes and the Engineering and the Environmental Impacts of Karst, Proceedings of the 11th Multidisciplinary Conference on Sinkholes, September 22-26, 2008, Tallahassee, Fla., ASCE Geotechnical Special Publication No. 183, P. 680-693.

Niemiller, Matt. 2008. Photos of Berry Cave Salamander. Available from: http://www.herpetology.us/ niemiller/

Stephenson, J. B. and B. Beck, 1995. Management of the discharge quality of highway runoff in karst areas to control impacts to groundwater - A review of relevant literature: in Beck, B.F., ed., Karst Geohazards - Engineering and Environmental Problems in Karst Terrane, Proceeding of the Fifth Multidisciplinary Conference on Sinkholes and the Engineering and Environmental Impacts of Karst, Gatlinburg, Tennessee, April 2-5, 1995, p. 297-321.

Stephenson, J. B., W.F. Zhou, B. Beck, and T. Green, 1997. Management of highway storm water runoff in karst areas - baseline monitoring and design of a treatment system for a sinkhole at the I-40/I-640 interchange in eastern Knoxville, Tennessee. In Proceedings of the 48th Annual Highway Geology Symposium, Knoxville, Tenn., May 8-10, p. 24-34. 
